\title{
FUEL CONSUMPTION OF A TRACTOR IN FUNCTION OF WEAR, OF BALLASTING AND TIRE INFLATION PRESSURE
}

\section{ROGER T. SPAGNOLO ${ }^{1}$, CARLOS E. S. VOLPATO ${ }^{2}$, JACKSON A. BARBOSA ${ }^{3}$, MARCOS A. Z. PALMA ${ }^{4}$, MURILO M. DE BARROS ${ }^{5}$}

\begin{abstract}
When using appropriate inflation pressures and load capacity (ballast), it may obtain a higher yield and prolongation of the life of the tire, besides it may minimize the problems of loss of traction, increased slippage and fuel consumption. This study aimed to evaluate the fuel consumption of a tractor operating with new and worn tires in three conditions of ballasting and three inflation pressures, when driving on compacted soil with vegetation cover. The experiment was conducted at the experimental unit from the Department of Animal Science, Federal University of Lavras, state of Minas Gerais, Brazil, in an agricultural soil compacted by cattle trampling and with vegetation cover. It was used a tractor $4 \times 2$ with front wheel assist, of a $65.62 \mathrm{~kW}$ engine power. The tires were of R1 type, diagonal (front: 12.4 to 24 ; and rear: 18.4 to 30 ), the average height of the clutches of the new tires were 0.3 and $0.35 \mathrm{~m}$ for front and rear tires, respectively, and for the worn tires were 0.018 and $0.0045 \mathrm{~m}$, for the front and the rear tires, respectively. The results showed advantages for the tractor equipped with new tires.
\end{abstract}

KEYWORDS: agricultural machinery, tractor test, tractive force.

\section{CONSUMO DE COMBUSTÍVEL DE UM TRATOR EM FUNÇÃO DO DESGASTE, DA LASTRAGEM E PRESSÃO DE INFLAÇÃO DOS PNEUS}

RESUMO: Ao se utilizar pressão de inflação e a capacidade de carga (lastro) adequadas, pode-se obter um rendimento maior e um prolongamento da vida útil do pneu; além disso, minimizam-se os problemas de perda de tração, aumento de patinhagem e consumo de combustível. O presente trabalho teve como objetivo avaliar o consumo de combustível de um trator agrícola operando com pneus novos e desgastados, em três condições de lastragem e três pressões de inflação, ao trafegar sobre solo compactado com cobertura vegetal. $\mathrm{O}$ experimento foi realizado na unidade experimental do Departamento de Zootecnia da Universidade Federal de Lavras, Lavras-MG, em um solo compactado pelo pisoteio de bovinos e com cobertura vegetal. Utilizou-se um trator $4 \times 2$ TDA, com potência de $65,62 \mathrm{~kW}$ no motor. Os pneus foram do tipo R1, diagonal (dianteiros: 12,4-24; traseiros: 18,4-30), sendo que a altura média das garras dos pneus novos foi de 0,3 e $0,35 \mathrm{~m}$ para os pneus dianteiros e traseiros, respectivamente, e nos pneus desgastados, 0,018 e 0,0045 m para os pneus dianteiros e traseiros, simultaneamente. Os resultados evidenciaram vantagens para o trator quando equipado com pneus novos.

PALAVRAS-CHAVE: máquinas agrícolas, ensaio de trator, força de tração.

\footnotetext{
${ }^{1}$ Doutorando em Agronomia, Departamento de Engenharia Rural, Universidade Federal de Pelotas, Pelotas - RS, Fone: (0XX53) 32757126, roger.toscan@gmail.com.

${ }^{2}$ Prof. Doutor, Departamento de Engenharia, Universidade Federal de Lavras, Lavras - MG.

${ }^{3}$ Prof. Doutor, Departamento de Engenharia, Universidade Federal de Lavras, Lavras - MG.

${ }^{4}$ Doutorando em Engenharia Agrícola, Departamento de Engenharia, Universidade Federal de Lavras, Lavras - MG.

${ }^{5}$ Doutorando em Engenharia Agrícola, Departamento de Engenharia, Universidade Federal de Lavras, Lavras - MG.

Recebido pelo Conselho Editorial em: 27-8-2010

Aprovado pelo Conselho Editorial em: 28-10-2011
} 


\section{INTRODUCTION}

The fuel consumption for agricultural tractors is the factor that sensitizes the farmer in order to search for information about maintenance and optimization of the tractor use. According to SALVADOR et al. (2009), the soil surface and the operations to be performed interfere with the fuel consumption of a tractor. Regardless of soil type and activity to be performed, it should always be aware of the characteristics of the tires, because the wheels of the tractor has the function of providing support, sustentation, guidance and self-locomotion, and are responsible for generating tractive effort (MIALHE, 1996). Among the different characteristics of the tires that affect the tractor operational performance are the type of tire, inflation pressure and ballasting. The adequacy of these tires characteristics influence the tire-soil interaction for the various agricultural operations, providing greater traction efficiency (MAZETTO et al., 2005).

Comparing new and worn tires, FRANZ (1988) found lower values of specific fuel consumption when new tires were used, with greater height of the clutch. MIRANDA et al. (2000) reported that the use of new tires provides an economy of $2.2 \mathrm{~L}(6.9 \%)$ in fuel consumption per hectare. While JESUINO (2007) found values of $8.45 \%$ and $12.73 \%$ lower for hourly consumption of fuel on track with vegetation and in a firm soil track, respectively, when diagonal worn tires were used.

LOPES et al. (2003) evaluated the fuel consumption of a tractor, 4x2 with front wheel assist, varying the type of tire (radial, diagonal and low pressure), combining two conditions of tractor ballasting (with and without water in the tires) and four displacement speeds. They concluded that the ballasting with water ( $75 \%$ of the tire volume) showed lower specific fuel consumption, and this tended to raise with the increase of tractor speed, regardless of whether the tire have ballast or not.

The hourly and specific fuel consumption did not change significantly when the three conditions of liquid ballast of diagonal tires ( $0 \%$ of water, $37 \%$ of water, and $75 \%$ of water) were used by MONTEIRO et al. (2009) in a soil track with vegetation cover. When performing operation of harrowing in a mobilized soil, SERRANO et al. (2003) describes that the use of tires without liquid ballast and with additional ballasts on the front of the tractor caused an $11 \%$ reduction in fuel consumption per hectare, compared to the use of tires filled with $75 \%$ of its volume with water and the presence of additional ballasts on the front.

According to CHARLES (1984) and BASHFORD et al. (1993,) the lower the inflation pressure the greater the force on the drawbar. SERRANO (2008) describes the use of high tire inflation pressure leads to a reduction of approximately 3 to $5 \%$ in working capacity and a significant increase between 10 and $25 \%$ of fuel consumption per hectare, even in a good tire grip, reflected in the range of 7 to $15 \%$ of slippage.

Thus, this study aimed to evaluate the fuel consumption of a tractor with auxiliary front traction, while working on a compacted soil with vegetation cover, taking into account factors of the tread band wear, inflation pressure and ballasting.

\section{MATERIALS AND METHODS}

The research was developed at the Federal University of Lavras / UFLA in the city of Lavras, state of Minas Gerais, Brazil. The geographic location of the experimental area was defined by the coordinates $21^{\circ} 13 ' 50^{\prime \prime}$ south latitude and 44 $57^{\prime} 52^{\prime \prime}$ west longitude, of $917 \mathrm{~m}$ altitude. To the particle size characterization of the soil 54 samples were collected at a depth of $0.30 \mathrm{~m}$. It was used a digital penetrometer to characterize the mechanical resistance to penetration when the measures were observed up to $0.15 \mathrm{~m}$ deep. The soil water content was obtained through samples on the layer from 0 to $0.15 \mathrm{~mm}$, which remained in an oven with forced air at a temperature of $105^{\circ} \mathrm{C}$ for a period of 24 hours. The quantification of the plant dry matter present on the ground was possible by collecting 9 samples from a square meter of vegetation, which was dried at $75{ }^{\circ} \mathrm{C}$ until reaching constant weight. 
The area in which the experiment was conducted was initially explored for six years with the conventional cultivation of maize. After that, it was implanted Brachiaria pasture that had remained for eight more years with average density of two animal units per hectare, with a surface condition of firm agricultural soil without preparation and with vegetation cover, which has been grazed before the experiment.

The experiment was conducted in 54 randomized plots with $2 \times 3 \times 3$ factorial design (two levels of wear, three levels of inflation pressure and 3 levels of ballast), totaling 18 treatments and 3 repetitions. The two sets of tires used were diagonals, regarded as one new and one worn, and the new tires had an average height from the clutches of 0.3 and $0.35 \mathrm{~m}$, and the worn tires of 0.0045 and $0.018 \mathrm{~m}$ for the front and rear tires, respectively. Table 1 shows the three levels of inflation pressure, and Table 2 the three levels of ballast applied to the tires during the field experiment. Each plot occupied an area of $90 \mathrm{~m}^{2}(30 \times 3 \mathrm{~m})$ and, between plots, in the longitudinal direction, there was an interval of $15 \mathrm{~m}$ to perform maneuvers and transit machinery.

TABLE 1. Different levels of tire inflation pressure used in field experiment.

\begin{tabular}{ccc}
\hline Pressure & Pressure of Rear Tires $(\mathrm{kPa})$ & Pressure of Front Tires $(\mathrm{kPa})$ \\
\hline P1 & $180 \mathrm{kPa}$ & $165 \mathrm{kPa}$ \\
P2 & $138 \mathrm{kPa}$ & $125 \mathrm{kPa}$ \\
P3 & $110 \mathrm{kPa}$ & $83 \mathrm{kPa}$ \\
\hline
\end{tabular}

TABLE 2. Different levels of ballasting applied to the tractor during the field experiment.

\begin{tabular}{|c|c|c|c|}
\hline Ballasting & Designation & Tractor Weight $(\mathrm{kN})$ & Tractor Weight (\%) \\
\hline L1 & $\begin{array}{l}\text { Tires with water and } \\
\text { metallic ballasts }\end{array}$ & 45.24 & 100 \\
\hline L2 & $\begin{array}{l}\text { Tires with water and } \\
\text { without metallic ballasts }\end{array}$ & 41.87 & 92.55 \\
\hline L3 & $\begin{array}{l}\text { Tires without water and } \\
\text { metallic ballasts }\end{array}$ & 33.56 & 74.18 \\
\hline
\end{tabular}

The test tires were mounted on a tractor, Valtra brand, model BL 88, $4 \mathrm{X} 2$ auxiliary front traction (AFT) of $65.62 \mathrm{~kW}(88 \mathrm{HP})$ engine rated power, total weight with ballast of $45.24 \mathrm{kN}$ (4613 kgf), distributed in $38 \%$ on the front axle and $62 \%$ on the rear axle. The driving tractor worked in second gear at a reduced speed of $1750 \mathrm{rpm}$ on the engine, with auxiliary front traction activated. To obtain the tractive force in the drawbar and slippage, it was used a tractor brake, Massey Ferguson brand, model 290, with a total weight of $39.06 \mathrm{kN}$ (3983 kgf), which worked in reduced second gear of $1,750 \mathrm{rpm}$ on the engine.

The new tires used on the rear axle were Goodyear 18.4-30R1, on the front axle Fate 12.424R1 tires. As for the set of worn tires, on the rear axle it was used Pirelli 18.4-30R1 tires, and Firestone 12.4-24R1 tires on the front axle.

Quantification of force in the drawbar was possible with the help of a load cell of Kyowa brand, LOAD CELL model, Series No CA 3125, which was positioned between the drawbar of the driving tractor and on the front part of the tractor brake. The load cell was connected to a signal conditioner (Spider), which was connected to a portable microcomputer, responsible for storing and processing of generated data. The data collected in $\mathrm{mV}$ were converted to $\mathrm{kN}$, using a calibration curve according to eq.(1), resulting from the load cell calibration using a universal testing machine.

$$
\mathrm{F}=23.38 \mathrm{~L}+0.492
$$

In which:

$\mathrm{F}$ - force in $\mathrm{kN}$;

$\mathrm{L}$ - values in $\mathrm{mV}$ obtained with the signal conditioner. 
The power at the drawbar was calculated according to the force exerted on the bar and the displacement speed of the tractor, according to the following equation:

$$
\mathrm{Pb}=\mathrm{Ft} \quad \mathrm{v}
$$

In which:

$\mathrm{Pb}=$ Power at the drawbar $(\mathrm{kW})$;

$\mathrm{Ft}=$ Force at the drawbar $(\mathrm{kN})$;

$\mathrm{v}=$ displacement speed of the driving tractor $\left(\mathrm{m} \mathrm{s}^{-1}\right)$.

In order to characterize the fuel used, an analysis was conducted in the Chemistry laboratory, Varginha Faculty of Engineering, in the city of Varginha, state of Minas Gerais, which resulted in a density of $0.859 \mathrm{~g} \mathrm{~L}^{-1}$ at a temperature of $20{ }^{\circ} \mathrm{C}$.

Fuel consumption was measured by means of an Oval M-III electromechanical flowmeter through electrical pulses that were converted into $\mathrm{ml} \mathrm{sec}^{-1}$ by the digital flowmeter. The flowmeter was installed between the tank and the fuel injection pump. The nozzles, filters, feeding pump and injector pump returns were diverted from not to return fuel to the tank and prevent the fuel passage twice by the electromechanical flowmeter. The display of the flowmeter was programmed to record the pulse every 0.3 seconds. Data were filmed and later with the help of an Excel spreadsheet, were converted to liters per hour, depending on the consumption recorded by the flowmeter, the density of diesel fuel, according to eq.(3). And to express the fuel consumption per unit of drawbar power, the eq.(4) was used.

$$
\begin{aligned}
\mathrm{Ch} & =\frac{\left(\frac{\mathrm{C}}{\delta}\right)}{3600} \\
\mathrm{Cec} & =\frac{\mathrm{Ch} \rho}{\mathrm{Pb}}
\end{aligned}
$$

In which:

$\mathrm{Ch}$ - mean hourly fuel consumption, $\mathrm{L} \mathrm{h}^{-1}$;

$\mathrm{C}$ - mean fuel consumption registered on the plots, $\mathrm{mg} \mathrm{s}^{-1}$;

$\Delta$ - density of diesel oil, $\mathrm{mg} \mathrm{L}^{-1}$;

$\mathrm{Cec}$ - specific consumption, $\mathrm{g} \mathrm{kW} \mathrm{h}^{-1}$;

$\rho$ - density of the consumption depending on the temperature, $\mathrm{g} \mathrm{L}^{-1}$;

$\mathrm{Pb}$ - power at the drawbar, $\mathrm{kW}$.

The values obtained were subjected to analysis of variance, and means were compared by Tukey test at $5 \%$ probability.

\section{RESULTS AND DISCUSSION}

According to the Department of Soil of the UFLA, the results of particle size analysis in the layer from 0 to $0.3 \mathrm{~m}$ had average values of $0.16,0.18$ and $0.66 \mathrm{~kg} \mathrm{~kg}^{-1}$ for sand, silt and clay, respectively. The average penetration resistance in the area, to a depth of $0.15 \mathrm{~m}$, was $2092.6 \mathrm{kPa}$, with a soil of average moisture of $25.69 \%$ and $14.97 \mathrm{t} \mathrm{ha}^{-1}$ of plant dry matter at the time of the tests. According to GABRIEL FILHO et al. (2010), the variation of temperature and density of fuel during the tests with tractors is less than $0.2 \%$, and thus the density was considered constant in the trial.

In Table 3, it was found significant differences between the factors tire, ballast, and pressure, with regard to hourly and specific fuel consumption. It was also noted that the use of worn tires resulted in a lower hourly fuel consumption of the tractor in relation to the use of new tires. This occurred because the use of new tire on the tractor has generated a greater development of force at 
the drawbar, which led to greater slippage and consequent increase in the volumetric consumption of fuel. According to GABRIEL FILHO et al. (2010) tires with lower clutches adhere better to firm soil, which contributes to the reduction of slippage. The increase in strength and power at the drawbar, when new tires were used, reflected in lower specific fuel consumption.

TABLE 3. Analysis of variance summary and mean tests for slippage variables, force at the drawbar, power at the drawbar, hourly fuel consumption, and specific fuel consumption.

\begin{tabular}{|c|c|c|c|c|c|}
\hline \multirow[b]{2}{*}{ Factors } & \multirow[b]{2}{*}{ Slippage (\%) } & \multirow{2}{*}{$\begin{array}{l}\text { Force at the } \\
\text { Drawbar }(\mathrm{kN})\end{array}$} & \multirow{2}{*}{$\begin{array}{l}\text { Power at the } \\
\text { Drawbar }(\mathrm{kW})\end{array}$} & \multicolumn{2}{|c|}{ Fuel Consumption } \\
\hline & & & & $\begin{array}{l}\text { Hourly } \\
\left(\mathrm{L} \mathrm{h}^{-1}\right)\end{array}$ & $\begin{array}{c}\text { Specific } \\
\left(\mathrm{g} \mathrm{kW} \mathrm{h}^{-1}\right)\end{array}$ \\
\hline \multicolumn{6}{|l|}{ Tire $(\mathrm{T})$} \\
\hline New & $20.10 \mathrm{a}$ & $19.58 \mathrm{a}$ & $17.01 \mathrm{a}$ & $10.09 \mathrm{a}$ & $514.25 \mathrm{~b}$ \\
\hline Worn & $11.94 \mathrm{~b}$ & $15.84 \mathrm{~b}$ & $14.66 \mathrm{~b}$ & $9.89 \mathrm{~b}$ & $601.75 \mathrm{a}$ \\
\hline \multicolumn{6}{|l|}{ Pressure (P) } \\
\hline $180 / 165 \mathrm{kPa}$ & $16.39 \mathrm{ab}$ & $17.56 \mathrm{ab}$ & $15.81 \mathrm{a}$ & $9.79 \mathrm{~b}$ & $536.59 \mathrm{~b}$ \\
\hline $138 / 125 \mathrm{kPa}$ & $17.38 \mathrm{a}$ & $18.58 \mathrm{a}$ & $16.22 \mathrm{a}$ & $10.09 \mathrm{a}$ & $554.52 \mathrm{ab}$ \\
\hline $110 / 83 \mathrm{kPa}$ & $14.28 \mathrm{~b}$ & $16.99 \mathrm{~b}$ & $15.48 \mathrm{a}$ & $10.09 \mathrm{a}$ & $582.89 \mathrm{a}$ \\
\hline \multicolumn{6}{|l|}{ Ballasting (B) } \\
\hline $100 \%$ & $14.66 \mathrm{~b}$ & $19.73 \mathrm{a}$ & $17.83 \mathrm{a}$ & $10.01 \mathrm{ab}$ & $486.61 \mathrm{c}$ \\
\hline $92,55 \%$ & $15.63 \mathrm{ab}$ & $17.35 \mathrm{~b}$ & $15.58 \mathrm{~b}$ & $10.05 \mathrm{a}$ & $565.81 \mathrm{~b}$ \\
\hline $74,18 \%$ & $17.77 \mathrm{a}$ & $16.06 \mathrm{~b}$ & $14.09 \mathrm{c}$ & $9.91 \mathrm{~b}$ & $621.59 \mathrm{a}$ \\
\hline \multicolumn{6}{|l|}{ F Test } \\
\hline $\mathrm{T}$ & $87.10 * *$ & $70.25 * *$ & $53.62 * *$ & $29.50 * *$ & $41.99 * *$ \\
\hline $\mathrm{P}$ & $4.36 *$ & $4.38 *$ & $1.79 \mathrm{~ns}$ & $31.36 * *$ & $3.99 *$ \\
\hline B & $4.41 *$ & $23.21 * *$ & $45.77 * *$ & $4.94 *$ & $33.64 * *$ \\
\hline $\mathrm{T} X \mathrm{P}$ & $5.92 * *$ & $10.98 * *$ & $9.88 * *$ & $50.09 * *$ & $4.77 *$ \\
\hline $\mathrm{T} X \mathrm{~B}$ & $11.57 * *$ & $8.36 * *$ & $7.08 * *$ & $33.70 * *$ & $8.60 * *$ \\
\hline P X B & $0.44 \mathrm{~ns}$ & $5.96 * *$ & $9.02 * *$ & $2.12 \mathrm{~ns}$ & $8.33 * *$ \\
\hline T X P X B & $0.11 *$ & $1.80 \mathrm{~ns}$ & $2.92 *$ & $9.86 * *$ & $4.28 * *$ \\
\hline C.V. (\%) & 20.05 & 9.25 & 7.47 & 1.31 & 8.89 \\
\hline
\end{tabular}

For each factor, means followed by the same lower-case letter in the column do not differ by the Tukey test, at 5\% of probability, and means not followed by any letter imply an interaction between factors ns - Non-significant $(\mathrm{p}>0,05)$; * - Significant $(\mathrm{p}<0,05)$; ** - Significant $(\mathrm{p}<0,01)$; C.V. - Coefficient of variation

To further elucidate the results of fuel consumption, it was necessary to unfold the interactions tire, pressure and ballast, according to the data analysis of variance presented in Table 3.

In Table 4, it is observed that the use of new tires with a pressure of 180 and $165 \mathrm{kPa}$ in the front and rear tires, respectively, resulted in lower hourly fuel consumption to the tractor when compared to other treatments, and this was the only level of pressure which presented significant difference in volumetric fuel consumption, considering the use of each tire individually.

TABLE 4. Unfolding of the interaction between tire and inflation pressure for the hourly fuel consumption $\left(\mathrm{L} \mathrm{h}^{-1}\right)$.

\begin{tabular}{lccc}
\hline \multirow{2}{*}{ Tire } & \multicolumn{3}{c}{ Inflation Pressure } \\
\cline { 2 - 4 } & $180 / 165 \mathrm{kPa}$ & $138 / 125 \mathrm{kPa}$ & $110 / 83 \mathrm{kPa}$ \\
\hline New & $9.64 \mathrm{bB}$ & $10.35 \mathrm{aA}$ & $10.27 \mathrm{aA}$ \\
Worn & $9.94 \mathrm{aA}$ & $9.83 \mathrm{bA}$ & $9.91 \mathrm{bA}$ \\
\hline
\end{tabular}

Means followed by the same lower-case letter in the column, and means followed by the same capital letter in the row do not differ by the Tukey test, at $5 \%$ of probability. 
When the two tires were compared, it is observed that the tractor had a higher hourly fuel consumption when the new tires were used with lower pressure. While with higher levels of pressure (P1), the hourly fuel consumption of the tractor equipped with worn tires was higher than the use of new tires. Treatment P1 was the only one in which the tractor with worn tires had a higher slippage than when comparing with the use of new tires, which may explain the higher fuel consumption. According to SILVEIRA (1988), the increase of inflation pressure causes the increase in slippage rates and consequent increase in fuel consumption.

Considering the behavior of each individual tire, the tractor with new tires had higher volumetric fuel consumption when the lowest ballasting (L3) was used, while the tractor with worn tires presented lower volumetric fuel consumption in this condition of ballasting, as observed in Table 5. Note also that there was no significant difference between the use of the two tires in relation to the hourly fuel consumption in relation to the variation of ballasting, except the lowest index of ballasting (L3), being the tractor without metallic ballasts or water ballast, indicating an unfavorable increase in consumption of $5.78 \%$, being the tractor equipped with new tires. This fact may be explained, because reducing the ballasting when new tires were used, led to significantly higher rates of slippage, also increasing the hourly fuel consumption, confirming the results obtained by CORRÊA (1993).

TABLE 5. Interaction between tire and ballasting for the hourly fuel consumption $\left(\mathrm{L} \mathrm{h}^{-1}\right)$.

\begin{tabular}{lcrr}
\hline \multirow{2}{*}{ Tire } & \multicolumn{3}{c}{ Ballasting } \\
\cline { 2 - 4 } & $100 \%$ & $92.55 \%$ & $74.18 \%$ \\
\hline New & $10.06 \mathrm{aAB}$ & $9.99 \mathrm{aB}$ & $10.21 \mathrm{aA}$ \\
Worn & $9.95 \mathrm{aA}$ & $10.10 \mathrm{aA}$ & $9.62 \mathrm{bB}$ \\
\hline
\end{tabular}

Means followed by the same lower-case letter in the column, and means followed by the same capital letter in the row do not differ by the Tukey test, at $5 \%$ of probability.

Through the analysis of Figure 1, can be observed the highest hourly fuel consumption when new tires were used, and that the variation between the data is small. When analyzed only the data of the new tires, it is observed that the treatments B1T1 and B2T1 were the only ones that differed from the others, with lower hourly fuel consumption.

The technical way of expressing fuel consumption is through the unit of mass per unit of power $\left(\mathrm{g} \mathrm{kWh}^{-1}\right)$, known as specific fuel consumption. This technical form can be used to compare engines, tractors and equipments of different sizes and shapes (LOPES et al., 2003).

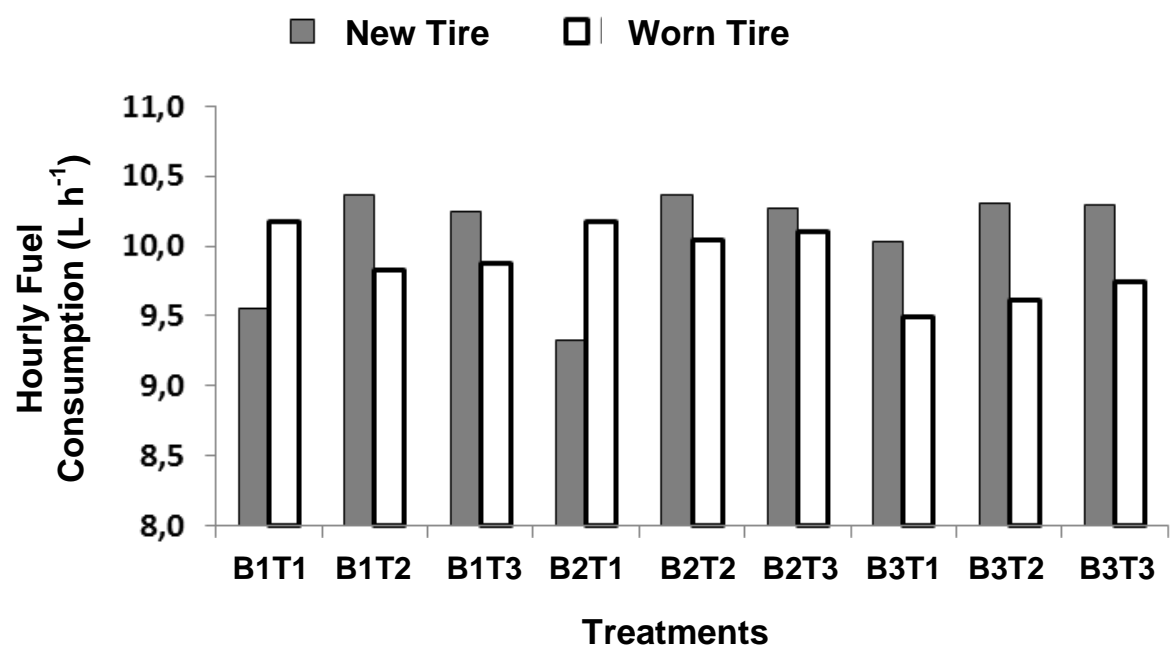

FIGURE 1. Comparison of the results of hourly fuel consumption of new tire and worn tire. 
In Table 6, it can be observed that, at different levels of inflation pressure used in new tires, the tractor does not present variation of specific fuel consumption, as opposed to the use of worn tires, which showed variation for all indexes, where fuel consumption was lower, the higher the inflation pressure. This fact can be explained, because higher rates of pressure resulted in higher values of power at the drawbar and, as the specific fuel consumption is a relation between volume consumption and power at the drawbar, the greater the power development in the drawbar, the lower the specific fuel consumption.

TABLE 6. Interaction between tire and inflation pressure for the specific fuel consumption $\left(\mathrm{g} \mathrm{kWh}^{-1}\right)$.

\begin{tabular}{lccc}
\hline Tire & \multicolumn{3}{c}{ Inflation Pressure } \\
\cline { 2 - 4 } & $180 / 165 \mathrm{kPa}$ & $138 / 125 \mathrm{kPa}$ & $110 / 83 \mathrm{kPa}$ \\
\hline New & $516.88 \mathrm{aA}$ & $508.32 \mathrm{bA}$ & $512.15 \mathrm{bA}$ \\
Worn & $554.48 \mathrm{aB}$ & $598.93 \mathrm{aAB}$ & $651.84 \mathrm{aA}$ \\
\hline
\end{tabular}

Means followed by the same lower-case letter in the column, and means followed by the same capital letter in the row do not differ by the Tukey test, at $5 \%$ of probability.

According to the data in Table 7, it is observed that the tractor equipped with no metallic or water ballasts, with new tires, had a higher specific fuel consumption. The tractor in the same conditions, but with worn tires had a mean specific consumption of $651.84 \mathrm{~g} \mathrm{kWh}^{-1}$, showing an increase of $14.97 \%$ in specific fuel consumption in relation to the use of the tractor with metallic and water ballasts. This result is in agreement with those found by LOPES et al. (2003). These authors concluded that the ballast with water ( $75 \%$ of the tire) offered to the tractor lower specific fuel consumption in comparison to the use of tires without water. While MONTEIRO et al. (2011), when working with a tractor equipped with diagonal tires, both on track with vegetation cover or firm surface track, pointed out that regardless of the amount of ballasts used in the tractor, there was not a significant variation in specific fuel consumption.

TABLE 7. Interaction between tire and ballasting for the specific fuel consumption $\left(\mathrm{g} \mathrm{kWh}^{-1}\right)$.

\begin{tabular}{lccc}
\hline Tire & \multicolumn{3}{c}{ Ballasting } \\
\cline { 2 - 4 } & $100 \%$ & $92.55 \%$ & $74.18 \%$ \\
\hline New & $480.55 \mathrm{aB}$ & $497.00 \mathrm{bB}$ & $559.80 \mathrm{bA}$ \\
Worn & $490.98 \mathrm{aB}$ & $632.87 \mathrm{aA}$ & $681.41 \mathrm{aA}$ \\
\hline
\end{tabular}

Means followed by the same lower-case letter in the column, and means followed by the same capital letter in the row do not differ by the Tukey test, at $5 \%$ of probability.

The specific fuel consumption of the tractor was greater with the use of worn tires, when the two types of tires are compared (Figure 2). This result corroborates with those found by FRANZ (1988) and MIRANDA et al. (2000), excepting only those cases where the highest rates of ballasting and pressure (B1T1) are used. It should be noted also that in Figure 2, the lowest specific fuel consumption was $423.35 \mathrm{~g} \mathrm{kWh}^{-1}$ and occurred in the treatment (B1T2), with the ballasted tractor, tires with water occupying $75 \%$ of its volume, and internal pressure of 138 and $125 \mathrm{kPa}$ in the front and rear tires, respectively. In the same treatment, the highest values occurred in the power at the drawbar, which corroborates the results reported by FRANZ (1988), who found minimum specific fuel consumption values, in which maximum power at the drawbar values were obtained. It is observed that the highest specific fuel consumption was $838.06 \mathrm{~g} \mathrm{kWh}^{-1}$ and occurred in the treatment B3T3, while the tractor was without ballast, with 110 and $83 \mathrm{kPa}$ of internal pressure in the worn front and rear tires, respectively. 


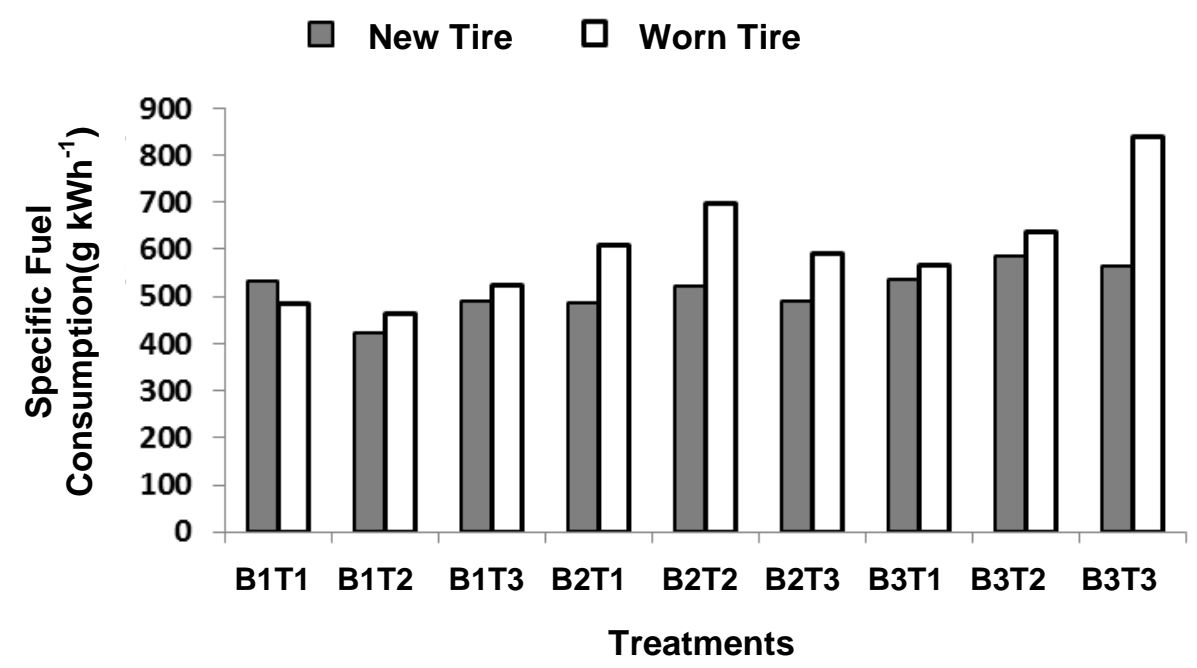

FIGURE 2. Comparison of the results of specific fuel consumption of new tire and worn tire.

By analyzing the inflation pressure of worn tires on different levels of ballasting, it is noted that the use of higher pressure (T1) did not cause significant variation in specific fuel consumption of the tractor for the different levels of ballasting, which was similar to what occurred with the use of new tires. The use of lower pressure (T3), while the tractor was without ballasts and without water in the tires, causes approximately a $37 \%$ increase in specific fuel consumption in relation to the use of tires with metallic and water ballast.

\section{CONCLUSIONS}

Lower levels of inflation pressure caused to the tractor an increased specific fuel consumption when worn tires were used. While higher rates of ballasting provided better traction conditions and lower specific fuel consumption when new tires were used. When comparing the use of new and worn tires, in all combinations of inflation pressure and ballasting tested, except the condition of higher inflation pressure and ballasting, the new tires provided better specific fuel consumption of the tractor which worked in a compacted soil with vegetation cover.

\section{REFERENCES}

BASHFORD, L.L.; AL-HAMED, S.; JANAME, C. Effects of tire size and inflation pressure on tractive performance. Applied Engineering in Agriculture, Saint Joseph, v. 9, n. 4, p.343-348, 1993.

CHARLES, S.M. Effects of ballast and inflation pressure on tractor tire performance. Agricultural Engineering, Saint Joseph, v.65, n.2, p.11-13, 1984.

CORRÊA, I. M. Características de tração de um trator agrícola utilizando-se de pneus radial e diagonal. 1993. 99 f. Dissertação de (Mestrado em Agronomia) - Escola superior de Agricultura "Luiz de Queiroz", Universidade de São Paulo, Piracicaba, 1993.

FRANZ, C.A.B. Avaliação do desempenho de pneumáticos para tratores agrícolas, com diferentes níveis de desgaste. 1988. 89 f. Dissertação (Mestrado em Engenharia Agrícola) - Universidade Federal de Santa Maria, Santa Maria, 1988.

GABRIEL FILHO, A.; MONTEIRO, L. de A.; LANÇAS, K.P.; GUERRA, S.P.S; JESUINO, P.R. Influência da altura das garras dos pneus de um trator em área de plantio direto. Revista Brasileira de Engenharia Agrícola e Ambiental, Campina Grande, v.14, n.10, 2010.

JESUINO, P.R. Desempenho de um trator agrícola em função do desgaste das garras dos pneus e das condições superficiais do solo. 2007. 64 f. Dissertação (Mestrado em Energia na Agricultura) Faculdade de Ciências Agronômicas, Universidade Estadual Paulista, Botucatu, 2007. 
LOPES, A.; LANÇAS, K.P.; FURLANI, C.E.A.; NAGOAKA, A.K.; CASTRO NETO, P. ; GROTTA, D. C. C. Consumo de combustível de um trator em função do tipo de pneu, da lastragem e da velocidade de trabalho. Revista Brasileira de Engenharia Agrícola e Ambiental, Campina Grande, v.7, n.2, p.382-386, 2003.

MAZETTO, F.R.; LANÇAS, K.P.; DA SILVA, R.B. Avaliação das áreas de contato de pnes agrícolas em função das cargas e pressões de insuflação em superfície rígida. Engenharia Agrícola, Jaboticabal, v.20, n.4, p.20-35, 2005.

MIALHE, L.G. Máquinas agrícolas: ensaios \& certificação. Piracicaba: FEALQ, 1996. 772 p.

MIRANDA, N. de O.; OLIVEIRA, M. de; NUNES, R.L. Desempenho operacional de trator com tração dianteira auxiliar na subsolagem de um inceptisol. Revista Brasileira de Engenharia Agrícola e Ambiental, Campina Grande, v.4, n.1, p.97-102, 2000.

MONTEIRO, L. de A.; LANÇAS, K.P.; FILHO, A.G. Desempenho um trator agrícola em função do tipo construtivo do pneu e da lastragem líquida em três velocidades de deslocamento na pista com superfície firme. Revista Energia na Agricultura, Botucatu, v.24, n.1, p.68-84, 2009.

MONTEIRO, L. de A.; LANCAS, K.P.; GUERRA, S.P.S. Desempenho de um trator agrícola equipado com pneus radiais e diagonais com três níveis de lastros líquidos. Revista Engenharia Agrícola, Jaboticabal, v.31, n.3, p.551-560, 2011.

SALVADOR, N.; MION, R.L.; BENEZ, S.H. Consumo de combustível em diferentes sistemas de preparo periódico realizados antes e depois da operação de subsolagem. Revista Ciência e Agrotecnologia, Lavras, v.33, n.3, p.870-874, 2009.

SERRANO, J.M.P.R. Pressão de insuflagem dos pneus no desempenho do conjunto trator-grade de discos. Pesquisa Agropecuária Brasileira, Brasília, v.43, n.2, p.277-233, 2008.

SERRANO, J.M.P.R.; PEÇA, J.O.; PINHEIRO, A.; CARVALHO, M.; NUNES, M.; RIBEIRO, L.; SANTOS, L. Ensaios de campo de tracção: Contribuição para a optimização do desempenho do tractor agrícola. Gazeta das Aldeias, Aveiro, n.3096, p.29-36, 2003.

SILVEIRA, G.M. Os cuidados com o trator. 2.ed. Rio de Janeiro: Globo, 1988. 245 p. 